\title{
Optimasi Kapasitas Bank Kapasitor Untuk Mereduksi Rugi-Rugi Daya Pada Penyulang Wortel Menggunakan Metode Grey Wolf Optimizer (GWO)
}

\author{
Christopher Theophilus Prayogo ${ }^{1}$, Osea Zebua ${ }^{2}$, Khairudin Hasan ${ }^{3}$ \\ Jurusan Teknik Elektro Universitas Lampung, Bandar Lampung \\ J1. Prof. Sumantri Brojonegoro No.1 Bandar Lampung 35145 \\ ${ }^{1}$ christopherpray22@gmail. com \\ ºsea.zebuadeng.unila.ac.id \\ ${ }^{3}$ khairudinhs@eng.unila.ac.id
}

Intisari - Jarak yang jauh antara sisi penyuplai energi listrik dan sisi konsumen (beban) pada jaringan distribusi menimbulkan permasalahan seperti meningkatnya rugi-rugi daya di sepanjang saluran dan jatuh tegangan. Pemasangan kapasitor adalah salah satu solusi untuk meminimalkan rugi-rugi daya sekaligus memperbaiki profil tegangan. Tujuan dari penelitian ini adalah mencari nilai kapasitas optimal dari beberapa bank kapasitor yang dipasang pada jaringan distribusi untuk meminimisasi rugi-rugi daya aktif menggunakan metode Grey Wolf Optimizer (GWO). Lokasi penempatan bank kapasitor ditentukan dengan menggunakan metode faktor sensitivitas rugi-rugi atau Loss Sensitivity Factor (LSF). Studi kasus yang digunakan adalah jaringan distribusi 20 kV Penyulang Wortel, di Gardu Induk Menggala, Provinsi Lampung. Simulasi penentuan lokasi penempatan dan optimasi kapasitas bank kapasitor dilakukan dengan menggunakan perangkat lunak MATLAB. Hasil simulasi menunjukkan bahwa lokasi optimal penempatan empat bank kapasitor menggunakan metode LSF adalah pada bus 42, 51,58 dan 60 dan kapasitas optimal bank kapasitor pada bus-bus tersebut yang diperoleh dengan menggunakan metode GWO masing-masing adalah sebesar 0,15 MVAR, 0,45 MVAR, 0,15 MVAR, dan 0,15 MVAR. Rugi-rugi daya aktif yang diperoleh setelah pemasangan bank kapasitor adalah sebesar 0,1041 MW atau berkurang sebesar $23 \%$ dari nilai rugirugi daya aktif sebelum pemasangan bank kapasitor yakni 0,1352 MW. Nilai tegangan minimum yang diperoleh setelah pemasangan bank kapasitor adalah 0,944 pu dan memperbaiki profil tegangan dari nilai tegangan minimum sebelum pemasangan bank kapasitor yakni sebesar $0,916 \mathrm{pu}$.

Kata-kata kunci - optimasi kapasitas, capacitor bank, Grey Wolf Optimizer, rugi-rugi daya aktif, faktor sensitivitas rugi-rugi.

Abstract - Long distance between the electricity supply side and the consumer side (load) on the distribution network can cause problems such as increasing power losses along the line and voltage drop. Installing capacitors is one solution to minimize power losses while improving the voltage profile. The aim of this research is to find the optimal capacity value of several capacitor banks installed in the distribution network to minimize active power losses using the Grey Wolf Optimizer (GWO) method. The location of the capacitor bank placement is determined by using the Loss Sensitivity Factor (LSF) method. The case study used is a $20 \mathrm{kV}$ distribution network of Wortel Feeders, in Menggala substation, Lampung Province. Simulation of determining the placement location and optimization of capacitor banks capacity is performed using MATLAB software. The simulation results show that the location of four capacitor banks using the LSF method is on buses 42, 51, 58 and 60 and the optimal capacitor bank capacity on those buses obtained using the GWO method are 0.15 MVAR, 0.45 MVAR, 0.15 MVAR, and 0.15 MVAR, respectively. The active power losses obtained after the installation of capacitor bank are equal to $0.1041 \mathrm{MW}$ or reduced by $23 \%$ from the value of active power losses before the installation of capacitor bank which is $0.1352 \mathrm{MW}$. The minimum voltage value obtained after the installation of capacitor bank is $0.94 \mathrm{pu}$ and improves the voltage profile of the minimum voltage value before the installation of capacitor bank which is equal to $0.916 \mathrm{pu}$.

Keywords - capacity optimization, capacitor bank, Grey Wolf Optimizer, active power losses, Loss Sensitivity Factor. 


\section{PENDAHULUAN}

Jaringan distribusi yang mempunyai saluran yang panjang dengan beban-beban listrik yang terhubung mempunyai resiko tingginya rugi-rugi daya pada saluran. Rugirugi daya pada saluran ini menghasilkan jatuh tegangan yang lebih besar dan dapat menurunkan profil tegangan pada setiap bus dimana beban-beban terhubung.

Pemasangan kapasitor merupakan salah satu cara untuk mengurangi rugi-rugi daya saluran sekaligus memperbaiki profil tegangan [1]. Namun penempatan kapasitor dengan kapasitas yang tidak optimal dapat menyebabkan peningkatan profil tegangan pada bus tertentu yang melebihi batas yang diizinkan, sehingga dapat mengakibatkan kerusakan pada beban-beban listrik. Karakteristik pembebanan yang tidak merata sepanjang hari perlu diperhatikan dan ikut menentukan kapasitas kapasitor yang akan dipasang.

Berbagai penelitian telah dilakukan untuk mencari lokasi dan kapasitas bank kapasitor pada jaringan distribusi dengan fungsi objektif yang berbeda-beda, baik menggunakan metode deterministik, seperti Mixed Integer Linear Progamming [2], Mixed Integer Non-Linear Progamming [3], maupun menggunakan metode optimisasi meta-heuristik, seperti Genetic Algorithm [4], Simulated Annealing [5], Fuzzy Logic [6], Tabu Search [7], Particle Swarm Optimization [8], Modified Artificial Bee Colony [9] dan Fuzzy Reasoning [10].

Salah satu metode optimisasi metaheuristik yang diusulkan adalah metode Grey Wolf Optimizer (GWO). Metode GWO telah digunakan untuk penyelesaian masalahmasalah optimisasi pada sistem tenaga listrik dengan hasil yang efisien.

Makalah ini menyajikan optimasi kapasitas bank kapasitor untuk meminimisasi rugi-rugi daya aktif sekaligus memperbaiki profil tegangan dengan menggunakan metode GWO. Lokasi penempatan bank kapasitor ditentukan dengan menggunakan metode Loss Sensitivity Factor (LSF). Studi kasus yang digunakan adalah kasus uji IEEE 10 bus dan Penyulang Wortel di Gardu Induk Menggala Provinsi Lampung.

\section{TINJAUAN PUSTAKA}

\section{A. Rugi-rugi Daya Pada Jaringan Distribusi}

Rugi-rugi daya pada jaringan distribusi biasanya merupakan rugi-rugi pada saluran dan rugi-rugi pada transformator. Rugi-rugi daya pada saluran terdiri dari rugi-rugi daya aktif dan rugi-rugi daya reaktif. Pada jaringan distribusi radial dengan $n$ bus, rugi-rugi daya aktif total dinyatakan dengan:

$$
P_{\text {totalloss }}=\sum_{i=1}^{n-1} P_{\text {loss }(i, i+1)}
$$

dimana $P_{\text {loss }(i, i+1)}$ adalah rugi-rugi daya aktif pada saluran yang menghubungkan bus $i$ dan bus $i+1$, yang dinyatakan dengan:

$$
P_{l o s s(i, i+1)}=I_{i}^{2} R_{i}
$$

\section{B. Faktor Sensitivitas Rugi-rugi}

Faktor sensitivitas rugi-rugi atau loss sensitivity factor (LSF) menyatakan sensitivitas rugi-rugi pada saluran terhadap besar beban daya reaktif pada salah satu bus. LSF dapat digunakan untuk memprediksi bus-bus yang menjadi kandidat untuk penempatan kapasitor [11]. Rangkaian ekivalen untuk perhitungan LSF ditunjukkan pada gambar 1 .

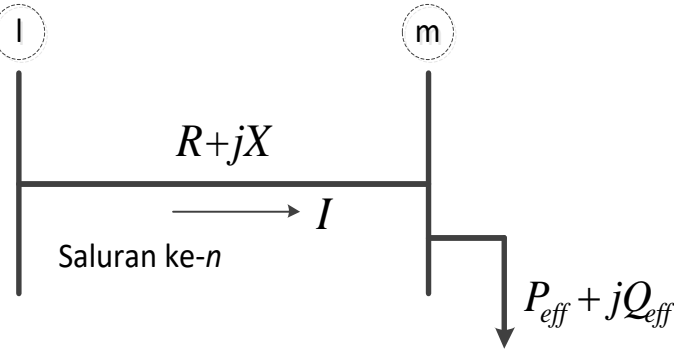

Gbr.1 Rangkaian ekivalen antar dua bus

Rugi-rugi daya aktif dan rugi-rugi daya reaktif pada saluran $n$ yang menghubungkan bus $l$ dan bus $m$ dengan impedansi $R[n]+j X[n]$ dan total daya efektif yang disuplai pada bus $m, P_{\text {eff }}+j Q_{\text {eff }}$, adalah: 


$$
P_{\text {loss }}[n]=\frac{\left(P_{\text {eff }}^{2}[m]+Q_{e f f}^{2}[m] R[n]\right)}{V[m]^{2}}
$$

dan

$$
Q_{\text {loss }}[n]=\frac{\left(P_{e f f}^{2}[m]+Q_{e f f}^{2}[m] X[n]\right)}{V[m]^{2}}
$$

Faktor sensitivitas rugi-rugi dihitung dengan persamaan:

$$
\begin{aligned}
& \frac{\partial P_{\text {lineloss }}}{\partial Q_{\text {eff }}}=\frac{\left(2 Q_{\text {eff }}^{2}[m] R[n]\right)}{V[m]^{2}} \\
& \frac{\partial Q_{\text {lineloss }}}{\partial Q_{\text {eff }}}=\frac{\left(2 Q_{\text {eff }}^{2}[m] X[n]\right)}{V[m]^{2}}
\end{aligned}
$$

Kandidat bus untuk penempatan bank kapasitor dipilih dengan memperhatikan nilai LSF untuk rugi-rugi daya aktif pada persamaan 5 dan norm tegangan bus $i$ terhadap tegangan minimum, yakni:

$$
\operatorname{norm}(i)=\frac{V_{i}}{V_{\min }}
$$

Nilai $V_{i}$ diperoleh dari perhitungan aliran daya sementara nilai $V_{\min }$ adalah nilai minimum yang diijinkan. Bila bus dengan nilai $\operatorname{norm}(i)$ kurang dari 1,01 dan nilai LSF daya aktif yang terbesar, maka bus tersebut dapat dipilih menjadi kandidat untuk penempatan bank kapasitor.

\section{Grey Wolf Optimizer}

Grey Wolf Optimizer (GWO) adalah suatu metode optimisasi metaheuristik berbasis kecerdasan kelompok atau populasi (swarm intelligence) yang diusulkan oleh Mirjalili dkk [12]. Metode optimisasi ini didasarkan pada hierarki sosial dan perilaku sekumpulan anjing serigala abu-abu (grey wolf) dalam memburu mangsa. Hierarki sosial ini mempengaruhi keputusan (solusi) akhir dalam perburuan mangsa, dengan tingkatannya dari yang teratas adalah serigala alpha, beta, delta, dan omega.

Langkah dalam metode GWO terdiri dari pelacakan (tracking), pengepungan (encircling), dan penyerangan mangsa (attacking prey) oleh para serigala abu-abu (search agent) sedemikian sehingga didapat tiga solusi yakni alpha $(\alpha)$, beta $(\beta)$, dan delta $(\delta)$, dengan alpha adalah solusi yang terbaik. Solusi selebihnya adalah omega $(\omega)$.

Pembaharuan dalam metode GWO dinyatakan dengan persamaan:

$$
\begin{aligned}
\vec{D}_{\alpha} & =\left|\vec{C}_{1} \cdot \vec{X}_{\alpha}-\vec{X}\right| \\
\vec{D}_{\beta} & =\left|\vec{C}_{1} \cdot \vec{X}_{\beta}-\vec{X}\right| \\
\vec{D}_{\delta} & =\left|\vec{C}_{1} \cdot \vec{X}_{\delta}-\vec{X}\right| \\
\vec{X}_{1} & =\vec{X}_{\alpha}-A_{1} \vec{D}_{\alpha} \\
\vec{X}_{2} & =\vec{X}_{\beta}-A_{1} \vec{D}_{\beta} \\
\vec{X}_{3} & =\vec{X}_{\delta}-A_{1} \vec{D}_{\delta} \\
\vec{X}(t+1) & =\frac{\vec{X}_{1}+\vec{X}_{2}+\vec{X}_{3}}{3}
\end{aligned}
$$

Dimana $\vec{D}_{\alpha}, \vec{D}_{\beta}$ dan $\vec{D}_{\delta}$ masing-masing adalah vektor jarak antara serigala alpha, beta dan delta terhadap serigala omega, $\vec{X}_{1}, \vec{X}_{2}$ dan $\vec{X}_{3}$ adalah vektor posisi terhadap alpha, beta dan delta, $\vec{X}$ adalah vektor posisi mangsa yang terus diperbaharui pada setiap iterasi. Sementara itu $\vec{A}$ dan $\vec{C}$ adalah vektor koefisien (coefficient vector) yang dihitung dengan persamaan:

$$
\begin{gathered}
\vec{A}=2 \vec{a} \cdot \vec{r}_{1}-\vec{a} \\
\vec{C}=2 \vec{r}_{2}
\end{gathered}
$$

dimana $\vec{r}_{1}$ dan $\vec{r}_{2}$ adalah vektor acak (random) yang bernilai antara 0 dan 1 , dan nilai $\vec{a}$ diset menurun secara linier dari 2 ke 0 sepanjang iterasi. 


\section{Optimasi Kapasitas Bank Kapasitor Menggunakan Metode GWO}

Optimasi kapasitas bank kapasitor menggunakan metode GWO dilakukan dengan fungsi objektif adalah meminimisasi rugi-rugi daya aktif dari jaringan distribusi atau dapat ditulis dengan persamaan:

$$
\min P_{\text {totalloss }}
$$

dengan memenuhi beberapa batasan pertidaksamaan (inequality constraint), antara lain:

- Batasan magnitude tegangan pada bus 1 (swing bus):

$$
V_{\min } \leq V_{1} \leq V_{\max }
$$

Nilai tegangan minimum dan maksimum masing-masing adalah $0,95 \mathrm{pu}$ dan 1,0 pu.

- Batasan kapasitas bank kapasitor:

$$
Q_{c i} \leq Q_{c i} \leq Q_{c i}^{\max }
$$

dimana kapasitas bank kapasitor yang dipasang pada bus $i$ merupakan kelipatan dari kapasitas terkecil, $Q_{c}^{0}$, dan ditulis dengan persamaan:

$$
Q_{c i}^{\max }=L \times Q_{c}^{0}
$$

dengan $L$ adalah bilangan integer dan $Q_{c}^{0}$ merupakan kapasitas terkecil dari standar bank kapasitor yang besarnya $50 \mathrm{kVAR}$.

\section{METODE PENELITIAN}

\section{A. Pemodelan Jaringan Distribusi}

Pemodelan jaringan distribusi dilakukan untuk perhitungan aliran daya menggunakan perangkat lunak MATPOWER [13]. Jaringan distribusi penyulang Wortel dan juga kasus uji IEEE 10 bus dimodelkan dengan model bus dan model saluran. Model bus terdiri dari data-data nomor bus, tipe bus, magnitude tegangan dan sudut tegangan, beban daya aktif dan daya reaktif setiap bus.
Model saluran meliputi data-data nomor saluran yang menghubungkan satu bus ke bus lainnya, dan nilai resistansi dan reaktansi saluran. Jumlah bus dan saluran di penyulang Wortel masing-masing adalah 113 bus dan 112 saluran. Sementara jumlah bus dan saluran pada kasus uji IEEE 10 bus masingmasing adalah 10 bus dan 9 saluran.

\section{B. Optimasi Penempatan dan Kapasitas Bank Kapasitor \\ Optimasi penempatan dan kapasitas} (rating) bank kapasitor dilakukan dengan mencari lokasi optimal penempatan bank kapasitor dengan menggunakan metode LSF, kemudian mencari kapasitas optimal bank kapasitor menggunakan metode GWO. Jumlah bus dimana bank kapasitor yang akan ditempatkan masing-masing adalah 5 bus pada kasus uji IEEE 10 bus dan 4 bus pada kasus penyulang Wortel.

Prosedur optimasi penempatan dan rating bank kapasitor pada kedua kasus dijelaskan sebagai berikut:

- Masukkan data-data untuk model bus dan model saluran.

- Hitung aliran daya jaringan distribusi.

- Hitung nilai LSF dan norm tegangan untuk setiap bus masing-masing menggunakan persamaan 5 dan 7. Cari kandidat bus dengan nilai norm tegangan yang kurang dari 1,01 dan nilai LSF yang terbesar.

- Hitung kapasitas optimal bank kapasitor untuk berbagai level beban yang meminimalkan fungsi objektif dengan menggunakan metode GWO. Pilih kapasitas yang paling besar dari kapasitas bank kapasitor yang diperoleh pada setiap level beban.

Dimensi pencarian pada kedua kasus adalah 5 , yakni tegangan pada bus 1 (bus generator) dan kapasitas bank kapasitor pada empat lokasi penempatan yang dihitung dengan menggunakan metode LSF. Parameter simulasi selengkapnya untuk optimasi kapasitas bank kapasitor menggunakan metode GWO ditunjukkan pada tabel 1. 
Tabel 1. Parameter Metode GWO

\begin{tabular}{|c|l|c|}
\hline No. & \multicolumn{1}{|c|}{ Parameter } & Nilai \\
\hline 1 & Dimensi pencarian & 5 \\
\hline 2 & Jumlah iterasi & 200 \\
\hline 3 & $\begin{array}{l}\text { Jumlah } \text { search } \\
\text { agent }\end{array}$ & 20 \\
\hline 4 & $\begin{array}{l}\text { Batas atas kapasitas } \\
\text { bank kapasitor }\end{array}$ & 2,1 MVAR \\
\hline 5 & $\begin{array}{l}\text { Batas bawah } \\
\text { kapasitas bank } \\
\text { kapasitor }\end{array}$ & $0,15 \mathrm{MVAR}$ \\
\hline 6 & $\begin{array}{l}\text { Batas atas magnitud } \\
\text { tegangan } \text { swing bus }\end{array}$ & $1,0 \mathrm{pu}$ \\
\hline 7 & $\begin{array}{l}\text { Batas bawah } \\
\text { magnitud tegangan } \\
\text { swing bus }\end{array}$ & $0,95 \mathrm{pu}$ \\
\hline
\end{tabular}

\section{HASIL DAN PEMBAHASAN}

\section{A. Kasus Uji IEEE 10 Bus}

Kasus uji ini memiliki basis tegangan operasi sebesar $23 \mathrm{kV}$ dan basis daya sebesar 100 MVA. Beban terdiri dari beban daya aktif total sebesar 12,368 MW dan beban daya reaktif total sebesar 4,186 MVAR. Diagram satu garis dari kasus uji IEEE 10 bus ditunjukkan pada gambar 2 .

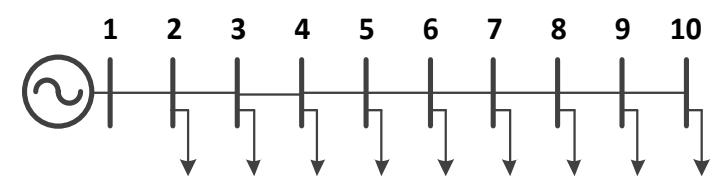

Gbr.2 Diagram Satu Garis Kasus Uji IEEE 10 Bus

Data beban dan saluran dari kasus uji IEEE 10 bus ditunjukkan pada tabel 2 .

Tabel 2. Data Beban dan Saluran Kasus Uji IEEE 10 Bus

\begin{tabular}{|c|c|c|c|c|c|}
\hline $\begin{array}{c}\text { Dari } \\
\text { bus }\end{array}$ & $\begin{array}{c}\text { Ke } \\
\text { Bus }\end{array}$ & $\begin{array}{c}\mathrm{P} \\
(\mathrm{kW})\end{array}$ & $\begin{array}{c}\mathrm{Q} \\
(\mathrm{kVAR})\end{array}$ & $\begin{array}{c}\mathrm{R} \\
(\mathrm{ohm})\end{array}$ & $\begin{array}{c}\mathrm{X} \\
(\mathrm{ohm})\end{array}$ \\
\hline 1 & 2 & 1840 & 460 & 0,1233 & 0,4127 \\
\hline 2 & 3 & 980 & 340 & 0,014 & 0,6057 \\
\hline 3 & 4 & 1790 & 446 & 0,7463 & 1,205 \\
\hline 4 & 5 & 1598 & 1840 & 0,6984 & 0,6084 \\
\hline 5 & 6 & 1610 & 600 & 1,9831 & 1,7276 \\
\hline 6 & 7 & 780 & 110 & 0,9053 & 0,7886 \\
\hline 7 & 8 & 1150 & 60 & 2,0552 & 1,164 \\
\hline 8 & 9 & 980 & 130 & 4,7943 & 2,716 \\
\hline 9 & 10 & 1640 & 200 & 5,3434 & 3,0264 \\
\hline
\end{tabular}

Hasil perhitungan aliran daya menunjukkan bahwa kasus uji IEEE 10 bus memiliki rugi-rugi daya aktif sebesar 0,7838 MW dan rugi-rugi daya reaktif sebesar 1,04 MVAR. Tegangan minimum yang diperoleh adalah sebesar 0,838 pu.

Hasil perhitungan empat lokasi terbaik untuk penempatan bank kapasitor menggunakan metode LSF ditunjukkan pada tabel 3 .

Tabel 3. Lokasi Penempatan Bank Kapasitor Pada Kasus Uji IEEE 10 Bus

\begin{tabular}{|c|c|c|c|}
\hline $\begin{array}{c}\text { Nomor } \\
\text { Bus }\end{array}$ & $\begin{array}{c}\text { Nilai } \\
\text { Tegangan } \\
(\mathrm{pu})\end{array}$ & Norm (i) & LSF \\
\hline 5 & 0,9480 & 0,9979 & 0,00959 \\
\hline 6 & 0,9172 & 0,9654 & 0,01120 \\
\hline 9 & 0,8587 & 0,9039 & 0,00866 \\
\hline 10 & 0,8375 & 0,8816 & 0,00576 \\
\hline
\end{tabular}

Hasil optimasi kapasitas bank kapasitor menggunakan metode GWO ditunjukkan pada tabel 4 .

Tabel 4. Hasil Optimasi Kapasitas Bank Kapasitor Pada Kasus Uji IEEE 10 Bus.

\begin{tabular}{|c|c|}
\hline No. Bus & $\begin{array}{c}\text { Kapasitas Bank } \\
\text { Kapasitor (MVAR) }\end{array}$ \\
\hline 5 & 2,1 \\
\hline 6 & 1,85 \\
\hline 9 & 0,35 \\
\hline 10 & 0,3 \\
\hline Total & 4,6 \\
\hline
\end{tabular}

Pemasangan bank kapasitor pada keempat bus dengan total injeksi daya reaktif sebesar 4,6 MVAR, menghasilkan rugi-rugi daya aktif sebesar 0,6849 MW atau berkurang sebesar $12,62 \%$. Tegangan minimum yang diperoleh adalah sebesar $0,88 \mathrm{pu}$.

Hasil simulasi lokasi pemasangan bank kapasitor menggunakan metode LSF dan optimasi kapasitas bank kapasitor menggunakan metode GWO dibandingkan dengan hasil simulasi dengan beberapa metode lainnya, seperti ditunjukkan pada tabel 5 . 
Tabel 5. Perbandingan Hasil Optimasi Beberapa Metode Untuk Kasus Uji IEEE 10 Bus.

\begin{tabular}{|l|c|c|c|c|}
\hline & $\begin{array}{c}\text { Fuzzy } \\
\text { Reasoning }\end{array}$ & $\begin{array}{c}\text { Modified } \\
\text { ABC }\end{array}$ & PSO & GWO \\
\hline $\begin{array}{l}\text { Rugi-rugi } \\
\text { daya aktif } \\
\text { total (MW) }\end{array}$ & 0,704883 & 0,69393 & 0,699103 & $\mathbf{0 , 6 8 4 9}$ \\
\hline $\begin{array}{l}\text { Reduksi } \\
\text { rugi-rugi } \\
\text { (\%) }\end{array}$ & 10,065 & 11,46 & 10,802 & $\mathbf{1 2 , 6 2}$ \\
\hline $\begin{array}{l}\text { Lokasi } \\
\text { bank } \\
\text { kapasitor }\end{array}$ & $4,5,6,9$ & $5,6,9,10$ & $5,6,9,10$ & $\mathbf{5 , 6 , 9 , 1 0}$ \\
\hline $\begin{array}{l}\text { Kapasitas } \\
\text { Optimal } \\
\text { (MVAR) }\end{array}$ & 1,$05 ; 1,05 ;$ & 1,$2 ; 1,2 ;$ & 1,$15 ; 1,05 ;$ & $\mathbf{2 , 1 ; 1 , 8 5 ;}$ \\
\hline $\begin{array}{l}\text { Total } \\
\text { (MVAR) }\end{array}$ & 4,95 & 0,$45 ; 0,15$ & 0,$4 ; 0,60$ & $\mathbf{0 , 3 5 ; 0 , 3}$ \\
\hline Vmax (pu) & 1,0 & 3 & 3,2 & $\mathbf{4 , 6}$ \\
\hline Vmin (pu) & 0,902 & 0,8715 & 0,8734 & $\mathbf{0 , 8 8}$ \\
\hline
\end{tabular}

Hasil perbandingan menunjukkan bahwa metode optimasi GWO jauh lebih efisien dalam segi peningkatan profil tegangan maupun penurunan rugi-rugi daya aktif dibandingkan dengan metode lainnya, sedangkan untuk kapasitas bank kapasitor yang digunakan masih lebih besar dibandingkan metode PSO dan Modified Artificial Bee Colony.

\section{B. Penyulang Wortel}

Penyulang Wortel adalah salah satu penyulang jaringan distribusi $20 \mathrm{kV}$ di gardu induk Menggala [14]. Penyulang ini dimodelkan dengan 113 bus dan 112 saluran. Penyulang mempunyai beban daya aktif total sebesar 2,65 MW dan beban daya reaktif sebesar 1,59 MVAR .Kurva beban harian dari penyulang Wortel ditunjukkan pada gambar 3 dengan durasi beban ditunjukkan pada tabel 6. Kurva beban harian dan durasi beban harian dibuat dengan estimasi level pembebanan karena keterbatasan pengukuran data, terutama pada gardu di transformator distribusi.

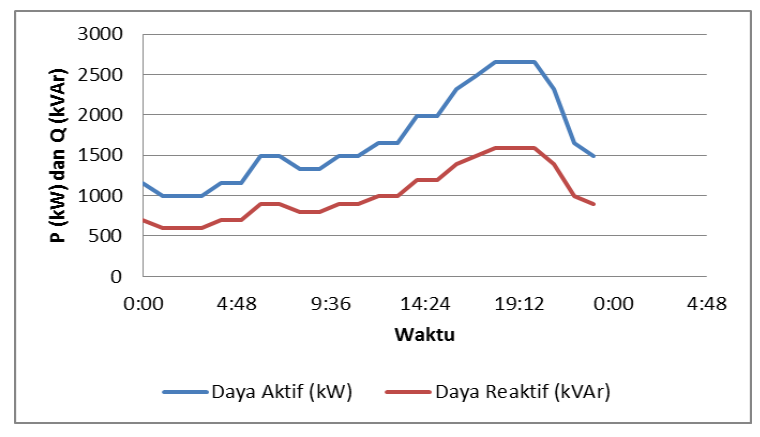

Gbr.3 Kurva beban harian penyulang Wortel
Hasil perhitungan aliran daya menunjukkan bahwa penyulang Wortel pada kondisi beban maksimum memiliki rugi-rugi daya aktif total sebesar $0,1352 \mathrm{MW}$ dan rugirugi daya reaktif total sebesar 0,22 MVAR . Diagram satu garis dari penyulang Wortel ditunjukkan pada gambar 4 .

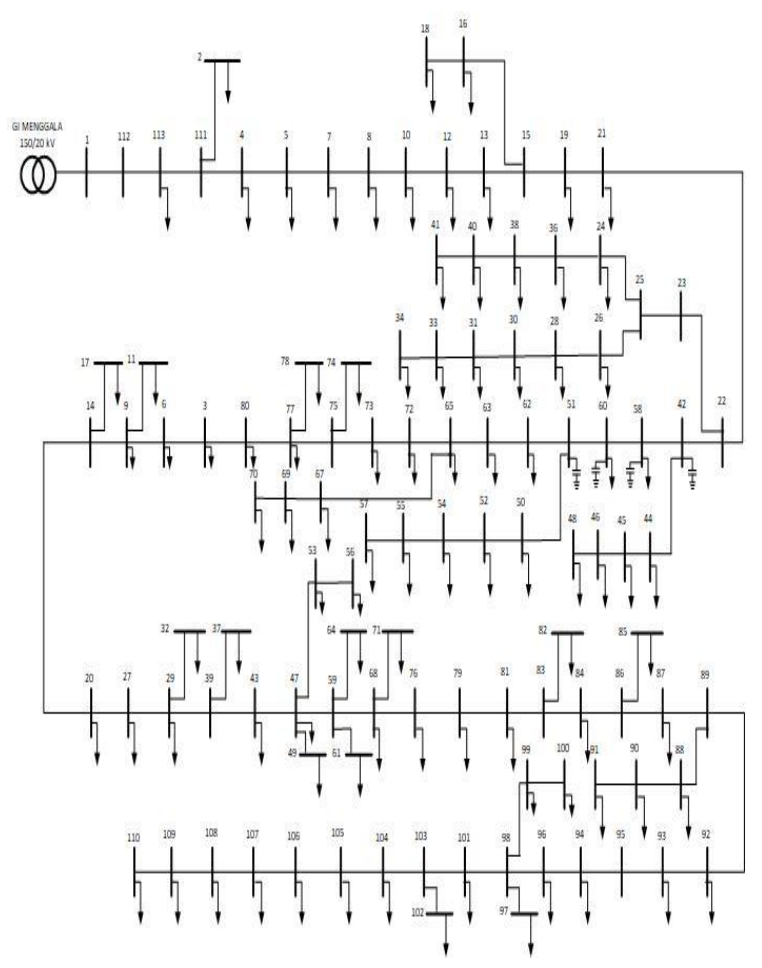

Gbr.4 Diagram Satu Garis Penyulang Wortel

Tabel 6. Durasi beban harian penyulang Wortel.

\begin{tabular}{|c|c|c|c|c|}
\hline $\begin{array}{l}\text { Kondisi } \\
\text { Beban }\end{array}$ & $\begin{array}{l}\text { Daya } \\
\text { Aktif } \\
\text { (MW) }\end{array}$ & $\begin{array}{c}\text { Daya } \\
\text { Reaktif } \\
\text { (MVAr) }\end{array}$ & $\begin{array}{c}\text { Perentase } \\
\text { Pembebanan } \\
(\%)\end{array}$ & $\begin{array}{l}\text { Durasi } \\
\text { Beban } \\
\text { (Jam) }\end{array}$ \\
\hline \multirow{3}{*}{ Pagi } & 0.993375 & 0.59775 & 30 & 3 \\
\hline & 1.1589375 & 0.697375 & 35 & 3 \\
\hline & 1.3245 & 0.797 & 40 & 2 \\
\hline \multirow{2}{*}{ Siang } & 1.4900625 & 0.896625 & 45 & 5 \\
\hline & 1.655625 & 0.99625 & 50 & 3 \\
\hline \multirow{2}{*}{ Sore } & 1.98675 & 1.1955 & 60 & 2 \\
\hline & 2.317875 & 1.39475 & 70 & 2 \\
\hline \multirow{2}{*}{ Malam } & 2.4834375 & 1.494375 & 75 & 1 \\
\hline & 2.649 & 1.594 & 80 & 3 \\
\hline \multicolumn{4}{|c|}{ Total durasi beban harian } & 24 \\
\hline
\end{tabular}

Beban terendah diasumsikan sebesar 30\%, sedangkan beban tertingginya diasumsikan sebesar $80 \%$ dari kapasitas transformator yang terpasang pada setiap bus.

Dengan menggunakan metode LSF diperoleh empat kandidat bus terbaik untuk penempatan bank kapasitor yang ditunjukkan pada tabel 7 . 
Tabel 7. Lokasi Penempatan Bank Kapasitor Pada Penyulang Wortel.

\begin{tabular}{|c|c|c|c|}
\hline $\begin{array}{c}\text { Nomor } \\
\text { Bus }\end{array}$ & $\begin{array}{c}\text { Nilai } \\
\text { Tegangan } \\
(\mathrm{pu})\end{array}$ & Norm (i) & LSF \\
\hline 42 & 0,959 & 1,00947 & 0,00172 \\
\hline 51 & 0,951 & 1,00105 & 0,00167 \\
\hline 58 & 0,956 & 1,00632 & 0,00172 \\
\hline 60 & 0,954 & 1,00421 & 0,00172 \\
\hline
\end{tabular}

Kapasitas bank kapasitor yang optimal dicari untuk setiap level pembebanan dengan menggunakan metode GWO. Nilai kapasitas yang terbesar menjadi nilai akhir kapasitas bank kapasitor. Nilai optimal kapasitas bank kapasitor yang diperoleh pada masingmasing bus ditunjukkan pada tabel 8 .

Tabel 8. Hasil Optimasi Kapasitas Bank Kapasitor Pada Penyulang Wortel.

\begin{tabular}{|c|c|}
\hline No. Bus & $\begin{array}{c}\text { Kapasitas Bank } \\
\text { Kapasitor (MVAR) }\end{array}$ \\
\hline 42 & 0,15 \\
\hline 51 & 1,45 \\
\hline 58 & 0,15 \\
\hline 60 & 0,15 \\
\hline Total & 1,9 \\
\hline
\end{tabular}

Rugi-rugi daya aktif total setelah pemasangan atau penempatan bank kapasitor pada keempat bus adalah sebesar 0,1041 MW pada kondisi beban $80 \%$ atau berkurang sebesar $23 \%$ dibandingkan sebelum pemasangan bank kapasitor.

Analisis pengaruh pemasangan bank kapasitor terhadap rugi-rugi daya aktif total pada setiap level pembebanan ditunjukkan pada gambar 3 .

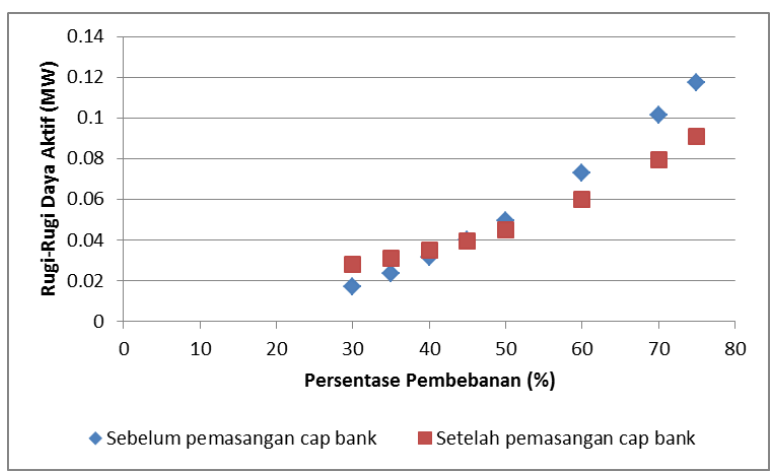

Gbr 5 .Pengaruh pemasangan bank kapasitor terhadap rugi-rugi daya aktif total
Gambar 5 menunjukkan bahwa pemasangan bank kapasitor dapat mereduksi rugi-rugi daya aktif total pada kondisi pembebanan antara $45 \%$ sampai $80 \%$, sementara pada kondisi pembebanan $30 \%$ sampai $40 \%$, rugi-rugi daya aktif lebih besar dibandingkan dengan rugi-rugi daya aktif tanpa pemasangan bank kapasitor.

Perbandingan nilai tegangan maksimum dan tegangan minimum sebelum dan setelah pemasangan bank kapasitor pada setiap kondisi pembebanan ditunjukkan pada gambar 6.

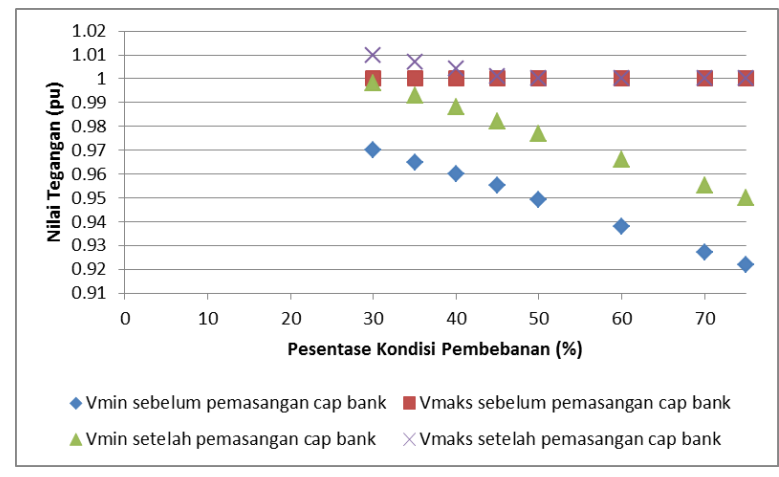

Gbr 6. Perbandingan nilai tegangan maksimum dan tegangan minimum pada setiap kondisi pembebanan.

Dari gambar 6 dapat dilihat bahwa tegangan maksimum dan tegangan minimum setelah penempatan atau pemasangan bank kapasitor lebih besar dari tegangan maksimum dan tegangan minimum sebelum penempatan bank kapasitor. Pada beberapa kondisi pembebanan yang rendah, tegangan maksimum setelah penempatan bank kapasitor bahkan lebih besar dari 1,0 per unit.

Tegangan minimum yang diperoleh setelah pemasangan bank kapasitor adalah sebesar $0,94 \mathrm{pu}$ sehingga memperbaiki profil tegangan minimum sebelum pemasangan bank kapasitor yakni sebesar 0,916 pu.

\section{PENUTUP}

Dengan menggunakan metode Loss Sensitivity Factor (LSF) untuk menentukan lokasi penempatan bank kapasitor, metode GWO dapat mencari kapasitas optimal bank kapasitor sekaligus mereduksi rugi-rugi daya aktif total, baik pada penyulang Wortel di Gardu Induk Menggala maupun pada kasus 
uji IEEE 10 bus. Bank kapasitor dengan kapasitas optimal yang diperoleh juga mampu memperbaiki profil tegangan pada setiap bus pada kedua kasus. Hasil yang diperoleh dengan menggunakan metode GWO lebih baik dibandingan hasil yang diperoleh menggunakan metode lainnya.

\section{REFERENSI}

[1] T. Gonen, Electric Power Distribution System Engineering Third Edition, CRC Press. Bacon Rota, United States, 2014.

[2] R. de Sa Fereira, A Mixed-Integer Linear Progamming Approach to the AC optimal Reactive Power Flow in Distribution System, Brasil, 2013.

[3] S. Kaur, G.B. Kumbhar and J. Sharma, Performance of Mixed Integer Non-Linear Progamming and Improve Harmony Search for Optimal Capacitor Placement of $D G$ units, IEEE Conference and Exposition on PES General Meeting. National Harbor, MD. USA. 2014.

[4] V. Ajjarapu and Z. Albanna, Application of Genetic Algorithm to Optimal Capacitor Placement, IEEE Proceedings of the First International Forum on Applications on Neural Networks to Power Systems. Seattle, WA. USA, 1991.

[5] T. Ghose, S.K. Goswani and S.K. Basu, Energy Loss Reduction in Distribution System by Capacitor Placement through Combined GA-SA Technique, IEEE Region 10 International Conference on Global Connectivity in Energy, Computer, Communication, and Control, New Delhi. vol. 2. pp. 502-505, 1998.

[6] S. M. Kannan, A. Rathina, G. Monica and S. M. R. Slochanal, Fuzzy Logic Based Optimal Capacitor Placement on Radial Distribution Feeders", Joint International Conference on Power System Technology and IEEE Power India Conference, pp.1-6. New Delhi, 2008.
[7] Y.C. Huang, H.T. Yang, and C.L. Huang, Solving the Capacitor Placement Problem a Radial Distribution System Using

Tabu Search Method, IEEE Transactions on Power Systems, vol.1, no.4, pp. 18681873, November, 1996.

[8] F.A. Anggara, O. Zebua, K. Hasan, Optimasi Penempatan dan Kapasitas Bank Capacitor Untuk Mereduksi Rugi- rugi Daya Menggunakan Kombinasi Metode Loss Sensitivity Factors dan Particle Swarm Optimization (PSO), Electrician Jurnal Rekayasa dan Teknologi Elektro, vol.12, no.2, hal.48- 56, Mei 2018.

[9] N. Gnanasekaran, S. Chandramohan, Maximum Cost Saving Approach for Optimal Capacitor Placement in Radial Distribution System Using Modified ABC Algorithm, International Journal on Electrical Engineering and Informatics, vol.8, no.4, India, 2015.

[10] C.T. Su and C.C. Tsai, A New Fuzzy Reasoning Aprroach to Optimum Allocation For Primary Distribution Systems, IEEE International Conference on Industrial Technology, Taiwan, 1996.

[11] K. Prakash and M. Sydulu, Particle Swarm Optimization based Capacitor Placement on Radial Distribution Systems, IEEE Conference on Power Engineering Society General Meeting, Tampa, Florida, United States, 2007.

[12] S. Mirjalili, S.M. Mirjalili and A. Lewis, Grey Wolf Optimizer, Advances in Engineering Software, vol.69, pp.46-61, 2014.

[13] R.D. Zimmerman, C.E. Murillo-Sanchez and R.J. Thomas, MATPOWER: Steady-state Operations, Planning and Analysis Tools for Power System Research and Education, IEEE Transaction on Power Systems, vol.26, no.1, pp.12-19, 2011.

[14] PT. PLN, One Line Diagram, PLN Distribusi Menggala, 2015. 